ARCHIVO ESPAÑOL DE ARTE, LXXXIX, 354

ABRIL-JUNIO 2016, pp. 202-209

ISSN: 0004-0428, eISSN: 1988-8511

doi: $10.3989 /$ aearte.2016.14

\title{
NUEVAS ESCULTURAS DE PEDRO DE MENA EN CÓRDOBA Y ESTEPA
}

\author{
Manuel García LuQue \\ Universidad de Granada \\ mgarcialuque@ugr.es
}

\begin{abstract}
En este trabajo incorporamos dos nuevas obras al catálogo del escultor granadino Pedro de Mena: una Santa Teresa, conservada en la iglesia de San Pedro Alcántara de Córdoba, y un San Pedro arrepentido, en la ermita de la Asunción de Estepa (Sevilla). Se le atribuyen por razones de técnica, formato y estilo y se analizan en comparación con otras obras seguras y firmadas, lo que permite estrechar su datación en el contexto de las décadas de 1670 y 1680.

Palabras clave: Mena, Pedro de; Santa Teresa; San Pedro arrepentido; Escultura barroca; Escultura policromada; Siglo XVII; Córdoba; Estepa (Sevilla).
\end{abstract}

\section{NEW SCULPTURES BY PEDRO DE MENA IN CORDOBA \& ESTEPA}

This article focuses on two new additions to the oeuvre of the Spanish sculptor Pedro de Mena: a small St Teresa of Ávila, in the church of St Peter Alcantara in Cordoba, and a St Peter penitent, in the hermitage of the Virgin of the Assumption in Estepa (Seville). Both attributions are based on stylistic and technical elements, as well as on their similarities with other documented and signed works by Mena, thereby suggesting a date between the decades of the 1670 s and 1680 s.

Key words: Mena, Pedro de; St Teresa; St Peter penitent; Baroque sculpture; Polychrome sculpture; 17th century; Cordoba; Estepa (Seville).

Se han cumplido cien años de la publicación del libro de Ricardo de Orueta sobre Pedro de Mena, monografía que con justicia se ha considerado pionera en su género ${ }^{1}$. En ella su autor ofreció el primer catálogo razonado de un escultor español, aunque como era de esperar el corpus de Mena ha ido enriqueciéndose y depurándose a lo largo de todo este tiempo ${ }^{2}$. Al repertorio de obras atribuidas al granadino podemos ahora añadir dos nuevas esculturas localizadas en Córdoba y Estepa (Sevilla), cuya atribución se razona en las líneas que siguen.

La primera de ellas es una pequeña escultura de Santa Teresa de Jesús ( $76 \mathrm{~cm}$ con peana), alojada en el ático del retablo colateral de la Epístola de la iglesia cordobesa de San Pedro Alcántara (fig. 1). La imagen se ha bajado recientemente para someterla a una limpieza y restauración, lo que ha permitido examinarla con detenimiento y descubrir que se trata de un original inédito de Pedro de Mena, al que nunca se le había prestado la suficiente atención ${ }^{3}$.

“Trabajo resultante del proyecto HAR2013-43976-P, financiado por el Ministerio de Economía y Competitividad'.

${ }^{1}$ Orueta y Duarte, 1914.

2 Véase la monografía de Gila Medina, 2007.

${ }^{3}$ En las diferentes guías artísticas de la ciudad simplemente se menciona su existencia, sin fecharla ni atribuirla. Mi agradecimiento a D. José Julio Martín Barba, rector del Seminario Redemptoris Mater, por las facilidades dadas para estudiar y fotografiar esta pieza. 


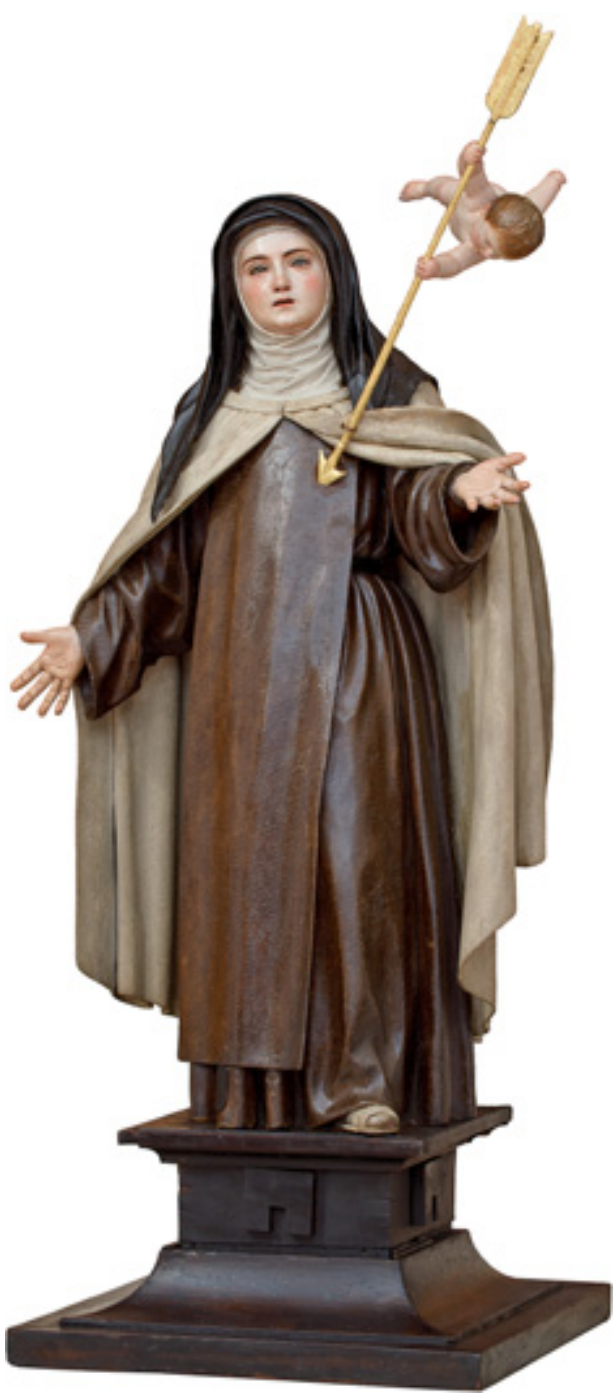

Fig. 1. Pedro de Mena. Santa Teresa de Jesús, ca. 1675. Córdoba, iglesia de San Pedro Alcántara.

La santa de Ávila aparece en pie, representada en el momento de su Transverberación, según describe ella misma en su autobiográfico Libro de la Vida:

Ví a un ángel cabe mí hacia el lado izquierdo en forma corporal $[\ldots]$. No era grande, sino pequeño [...]. Viale en las manos un dardo de oro largo, y al fin de el hierro me parecía tener un poco de fuego. Este me parecía meter por el corazón algunas veces, y que me llegaba a las entrañas. Al sacarle, me parecía las llevaba consigo y me dejaba toda abrasada en amor grande de Dios ${ }^{4}$.

En efecto, Mena ha representado a la reformadora del Carmelo en pleno arrebato espiritual mientras recibe con sus brazos abiertos el regalo místico del ángel. A pesar de lo contenido de la composición, el escultor sitúa a la santa en actitud de avanzar, asomando la zapatilla de esparto bajo el hábito para romper la frontalidad del escapulario.

La delicadeza del modelado alcanza cotas de miniatura en algunos detalles, como la dentadura, minuciosamente trabajada, o la fina talla de los dedos y las arrugas de las palmas. Los diminutos ojos de cristal acentúan el carácter naturalista de la imagen ${ }^{5}$, que a pesar de seguir los prototipos femeninos habituales en el escultor ${ }^{6}$, también se distingue por algunos pormenores de carácter retratístico, como las verrugas de la mejilla izquierda que aparecen en numerosas representaciones de la santa. Como es típico en Mena, la madera se adelgaza para simular los tejidos, hasta el punto de introducir una fina lámina entre el velo y la toca, tan frágil y moldeable como el cartón.

El querubín, que ha perdido las alas, se precipita airosamente sobre la santa (fig. 2). No medirá más de $10 \mathrm{~cm}$ y es asimismo representativo del arte más personal de Mena. Con sus cabellos rubios y sus ojos azules -también de cristal- recuerda muy de cerca al Niño de la Virgen de Belén de la catedral de Granada, o al de la Virgen del Pajarito de Purchil (Granada).

Por fortuna la pieza conserva su policromía original, que supone un perfecto correlato del volumen escultórico: tanto por la acertada elección cromática en tonos puros, que incide en este carácter naturalista de la imagen y permite concentrar toda la fuerza expresiva en el rostro; como por la propia técnica pictórica, que consigue crear diferentes texturas sobre la superficie escultórica. De este modo, la urdimbre del escapulario y del hábito marrón ha sido simulada con pequeños y sis-

\footnotetext{
4 Jesús, 1565 (1915): 234.

5 El ojo izquierdo, perdido, ha sido reconstruido en la reciente intervención.

${ }^{6}$ Por ejemplo, la Santa Clara de las Descalzas Reales.
}

Arch. esp. arte, LXXXIX, 354, ABRIL-JUNIO 2016, 202-209

ISSN: 0004-0428, eISSN: 1988-8511, doi: 10.3989/aearte.2016.14 


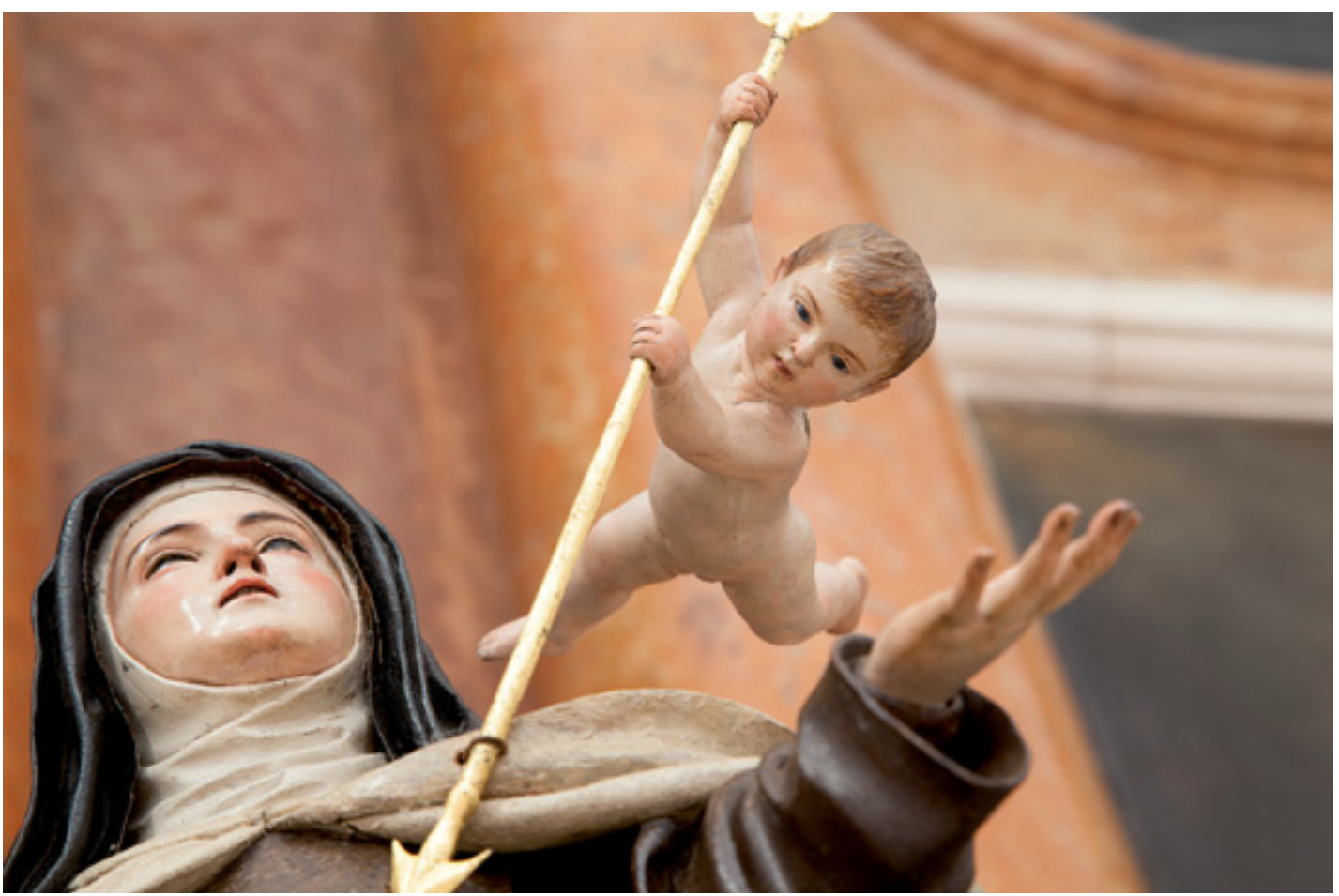

Fig. 2. Pedro de Mena. Santa Teresa de Jesús (detalle), ca. 1675. Córdoba, iglesia de San Pedro Alcántara.

temáticos toques de pincel cargados de empaste, que confieren calidades táctiles a la policromía. Es un recurso éste que reaparece en otras obras de pequeño formato de $\mathrm{Mena}^{7}$ y que demuestra hasta qué punto el acabado cromático desempeña un papel fundamental en la apreciación de sus esculturas, seguramente porque la policromía le fue aplicada en el mismo taller o bajo la directa supervisión del maestro.

Resulta evidente que una pieza como ésta, de delectación cercana, no se talló pensando en un emplazamiento elevado como el actual. Es del todo probable que la obra perteneciera en origen a un particular y solo en un momento posterior pasara al convento, quizás por vía de donación, pues de hecho el templo cordobés de los alcantarinos no se inauguró hasta 1696, cuando el escultor ya había fallecido ${ }^{8}$. En todo caso, la pieza ya debía estar allí en el siglo XIX, momento en el que debe encuadrarse la construcción de los dos retablos neoclásicos del crucero. Entonces fueron elegidas dos tallas de acarreo, de pequeño tamaño, para coronar los nichos del ático: un San Juan Bautista de Duque Cornejo, para el retablo de la nave del Evangelio ${ }^{9}$, y esta Santa Teresa, para el altar de la Epístola.

A juzgar por la peana -de ébano-, la obra ha de ser datada en la década de 1670, dada su estrecha cercanía con las empleadas en otras obras de pequeño formato que sí están fechadas y firmadas, como el San José y la Inmaculada de la iglesia de San Nicolás de Murcia (1674 y 1676),

${ }^{7}$ Especialmente en los hábitos de los santos franciscanos, como la ya comentada Santa Clara de las Descalzas Reales, el San Diego de Alcalá del Museo Diocesano de Vitoria o el San Pedro Alcántara recientemente aparecido en comercio de arte. Romero Torres, 2014: 139-157.

${ }^{8}$ Villar Movellán, 1995: 74.

${ }^{9}$ Esta obra, también inédita, se estudia en un trabajo en prensa.

Arch. esp. arte, LXXXIX, 354, ABRIL-JUNIO 2016, 202-209 ISSN: 0004-0428, eISSN: 1988-8511, doi: 10.3989/aearte.2016.14 
el San Juanito del Museo de Bellas Artes de Sevilla (1674) o la Santa Clara de las Descalzas Reales (1675). Este estrado, tan característico de Mena, está constituido por una base cuadrangular con perfil en nacela sobre la que descansa un cuerpo prismático, decorado a su vez con la típica placa recortada de herencia canesca, repetida en sus cuatro lados.

Hasta el momento resultaba extraño que entre la larga serie de santos realizados por Mena apenas hubiera lugar para una santa como la de Ávila - primera mujer canonizada tras la Contrarreforma-, que tanta devoción despertó en la España del Siglo de Oro. El escultor realizó un altorrelieve con el tema para la sillería de la catedral de Málaga y también se le atribuye una pequeña escultura policromada en la parroquial de Alhendín ${ }^{10}$, aunque en ambos casos optó por representarla redactando sus obras bajo la directa inspiración del Espíritu Santo. También consta que en 1688 don Antonio Manrique de Lara, protector malagueño de Mena, poseía, entre otras piezas de su mano, una Santa Teresa de Jesús que quizás podría identificarse con ésta ${ }^{11}$.

Fueron estas pequeñas imágenes de oratorio, de marcado acento naturalista y virtuosismo técnico, las que hicieron ganar a Mena gran prestigio y popularidad entre la clientela devota de su tiempo. Su interés por el pequeño formato procede del magisterio de Cano (recuérdense las delicadas tallas de la Inmaculada y la Virgen de Belén en la catedral de Granada), del propio medio artístico granadino en que se formó (donde abundaban los pequeños barros devocionales de los hermanos García) y de las propias incursiones que su padre hizo en el género ${ }^{12}$. En cualquier caso, esta predilección por la escala reducida también encuentra importantes puntos de contacto con la escultura napolitana del momento, especializada en la producción de santos de cuerpo entero en formato terzino (un tercio de la estatura real) para facilitar su comercialización ${ }^{13}$. Mena tuvo que familiarizarse con este tipo de imágenes durante su estancia en la Corte, entre 1663 y 1664, momento en que talla su célebre San Francisco para la catedral toledana.

En contraste con este género, ya tópico en la producción de Mena, la creación de imágenes de vestir con carácter procesional constituye una dimensión todavía poco valorada del escultor. Su relación con las hermandades de penitencia está constatada documentalmente ya desde sus primeras obras de juventud en Granada. En 1650 contrató unas andas con veinticuatro serafines para la cofradía de Nuestra Señora del Martirio de Ugíjar y en ese mismo año también esculpió un Crucificado articulado para la cofradía de la Veracruz de Íllora ${ }^{14}$. Esta relación con las hermandades rebrota en su etapa malagueña, como demuestra una carta que el escultor recibió en abril de 1669 de uno de sus intermediarios, el pintor Bernabé Jiménez de Illescas, en la que se hace mención a un Nazareno -hoy perdido- que el escultor había realizado para la cofradía de Pasión de Lucena ${ }^{15}$. Tres años más tarde, otra cofradía de esta misma ciudad cordobesa expresaba su deseo de encargar a Mena una imagen de Jesús Preso del que nada más se vuelve a saber, aunque poco tiempo después se constata la compra de un Jesús de la Humildad y de una Dolorosa de vestir que indudablemente salieron de su taller malagueño.

A este grupo cabe añadir un singular conjunto iconográfico del Lavatorio de los pies, integrado por las imágenes, también de vestir, de Jesús y San Pedro, que por fortuna se ha podido documentar fehacientemente y que el escultor debió realizar entre 1675 y $1679^{16}$. Precisamente, la reciente in-

\footnotetext{
${ }^{10}$ Henares Cuéllar / Félez Lubelza / Orozco Díaz, 1970: 81, cat. 89.

${ }^{11}$ Romero Torres, 1989: 105.

${ }^{12}$ Aunque no muy abundantes, existen algunas esculturas de pequeño formato atribuidas a Alonso de Mena, como el Crucificado de la capilla de la Residencia "La Milagrosa" de Armilla (Granada), o el Nazareno que se sitúa en el cancel del coro de legos del monasterio granadino de la Cartuja.

13 Alonso Moral, 2007: 75.

14 Sánchez-Mesa Martín, 1967: 248 (citando por un manuscrito inédito de Gómez-Moreno). Verdejo Martín, 2006:

${ }^{15}$ La carta la dio a conocer Valladar, 1915. Se estudia en García Luque, 2011-2012.

16 García Luque, 2013.
} 19-20.

Arch. esp. arte, LXXXIX, 354, ABRIL-JUNIO 2016, 202-209

ISSN: 0004-0428, eISSN: 1988-8511, doi: 10.3989/aearte.2016.14 


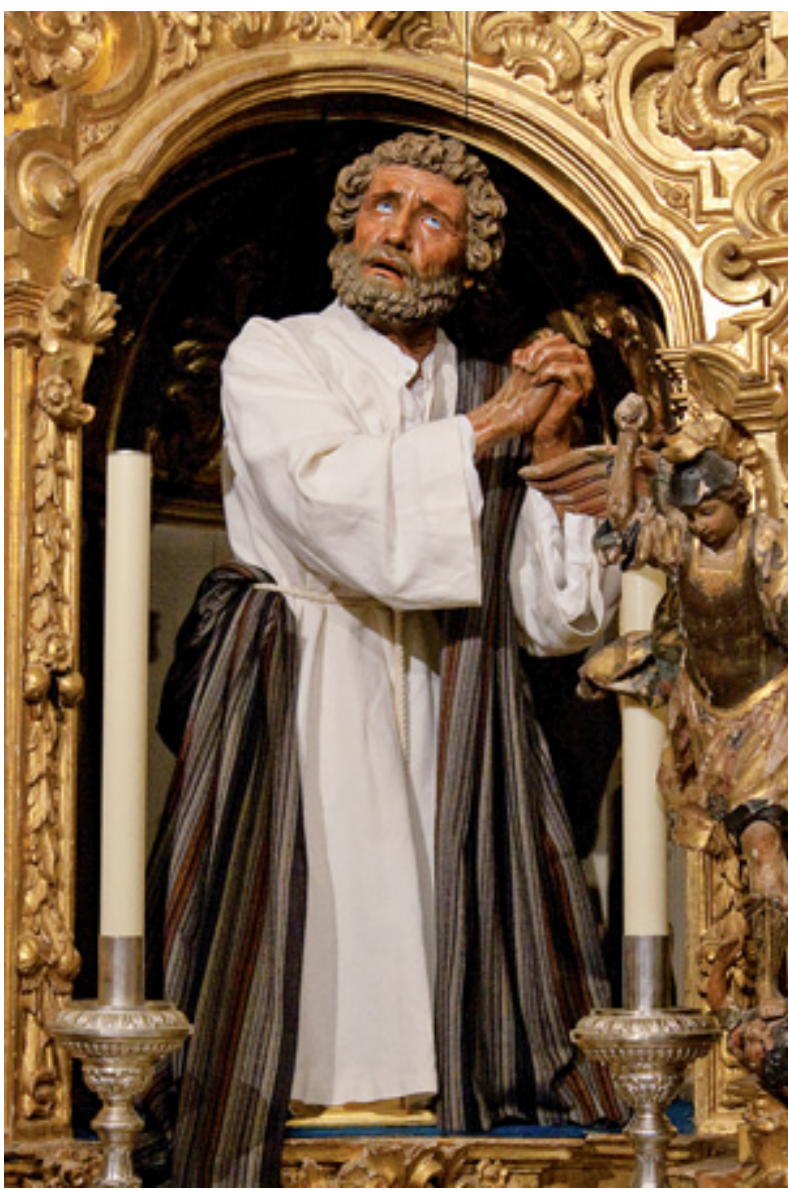

Fig. 3. Pedro de Mena. San Pedro arrepentido, ca. 1675-1688. Estepa, ermita de Nuestra Señora de la Asunción. corporación de este San Pedro del Lavatorio al catálogo de Mena permite reconsiderar la atribución de otra imagen de similares características: el San Pedro arrepentido de la iglesia de Nuestra Señora de la Asunción de Estepa (Sevilla) (fig. 3), obra que en alguna ocasión ha sido relacionada con el entorno escultórico de Pedro de Mena pero que jamás había sido considerada por quienes se han ocupado de la obra del granadino ${ }^{17}$.

En este caso se trata de una escultura de madera policromada de tamaño natural $(120 \mathrm{~cm})$, preparada para ser vestida, aunque completamente anatomizada. Representa el momento en que Pedro, arrepentido por haber negado a Cristo, se arrodilla y llora tras el canto del gallo. Tradicionalmente se sostenía que la imagen había formado parte de una hermandad de San Pedro existente en Estepa desde el siglo XVI, pero recientes investigaciones han demostrado que en realidad existieron dos corporaciones que rendían culto al santo: la primera ya mencionada, que, como era habitual en las asociaciones de este tipo, estaba integrada por los sacerdotes de la villa; y una segunda, formada por seglares y denominada de las "Lágrimas de Señor San Pedro", que con carácter penitencial se creó el 31 de diciembre de 1674. Según la escritura fundacional, esta segunda hermandad, radicada en la ermita de la

Asunción, habría de sacar en procesión la tarde del Miércoles Santo unas imágenes preexistentes del Cristo a la Columna y de Nuestra Señora. Como en este documento nada se dice de la imagen del titular, cabe sospechar que en principio no contaran con ella, aunque en cualquier caso tuvieron que encargarla no mucho después, pues consta que en 1688 ya procesionó por primera vez ${ }^{18}$.

${ }^{17}$ La obra, aunque tradicionalmente tenida como anónima, ha llamado la atención por su calidad desde antiguo. Aguilar y Cano (1888: 74) la describía como «de gran mérito artístico, por su franca y correcta ejecución, por su expresión llena de verdad, por sus exactas proporciones, por su naturalidad, y por su indisputable belleza. ¡Lástima que no podamos consignar el nombre de su autor!». Según una inverosímil tradición oral, la imagen del apóstol habría sido traída desde Italia a comienzos del siglo XVII. Hernández Díaz, Sancho Corbacho y Collantes de Terán (1955: 74) la calificaron de «obra barroca de intensa fuerza expresiva», sin sugerir nombre alguno. Sánchez López (2004: 162) la estimó obra anónima seiscentista, con grafismos cercanos a Alonso de Mena, mientras que al fin Díaz Fernández (2003: 100) acertó a considerarla más próxima al taller del hijo, aunque fechándola a mediados de siglo.

${ }^{18}$ El dato es conocido gracias a la anotación de un libro de defunciones parroquial, donde se registra que el 14 de abril de 1688 «se hizo procesión de las lágrimas de San Pedro, y salió de la Santa Veracruz por estar la ermita de Ntra. Sra. de la Asunción con necesidad de hacer obra; fue este el primer año». Fernández Flores, 2000: 195.

Arch. esp. arte, LXXXIX, 354, ABRIL-JUNIO 2016, 202-209 ISSN: 0004-0428, eISSN: 1988-8511, doi: 10.3989/aearte.2016.14 


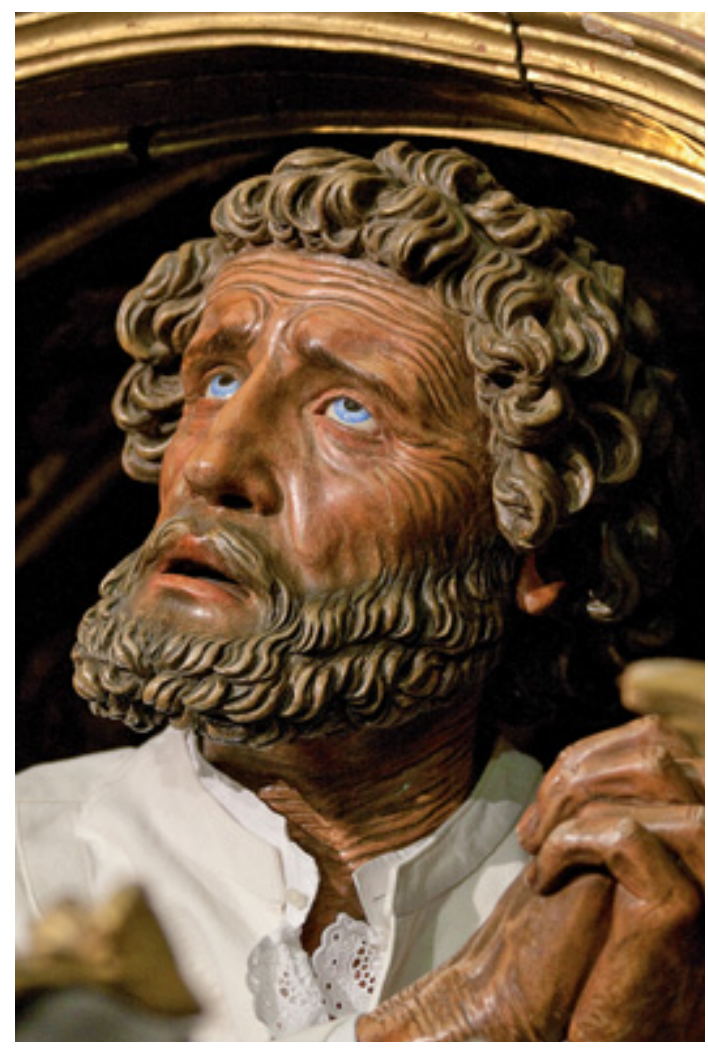

Fig. 4. Pedro de Mena. San Pedro arrepentido (detalle), ca. 1675-1688. Estepa, ermita de Nuestra Señora de la Asunción.

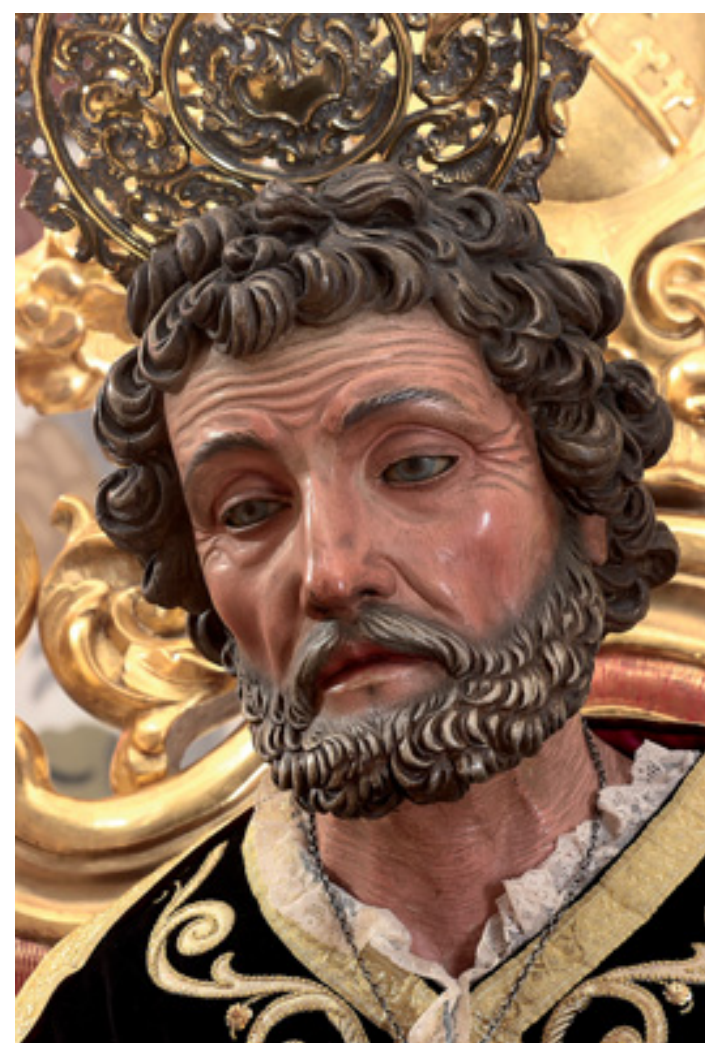

Fig. 5. Pedro de Mena. San Pedro (detalle), ca. 16751679. Lucena, ermita de Dios Padre.

Teniendo en cuenta esta nueva datación (1675-1688) y su indudable parentesco con el documentado San Pedro de Lucena, la atribución a Mena del ejemplar estepeño encaja a la perfección. De su comparación con aquél se evidencia la utilización de un mismo modelo, que en última instancia remite al pequeño San Pedro de la iglesia granadina de San Antón, obra de juventud de Mena ${ }^{19}$. Existen, claro está, divergencias de expresión entre uno y otro, pero esto se debe más a las propias exigencias del episodio iconográfico que al trabajo de dos personalidades artísticas diferentes ${ }^{20}$. En ambos casos, Mena ha representado a Simón Pedro como un anciano canoso, con cabello rizado y barba corta (figs. 4 y 5). El recurso de los mechones que enmarcan el rostro recuerda al peinado utilizado en sus distintas representaciones de San José, aunque quizás el vínculo más evidente sea el empleo de su inconfundible canon facial, con el mentón prominente y la nariz afilada. También es típicamente suyo el modo de reunir el tabique nasal y las cejas, conformando una flecha que subraya la mirada ascensional del apóstol. El modo de levantar las manos en

${ }^{19}$ Ceán Bermúdez, 1800: 112.

${ }^{20}$ También hay que tener en cuenta el distinto estado de conservación de las policromías. El San Pedro estepeño fue restaurado en 1991 por el escultor Francisco Berlanga de Ávila, mientras que no se conoce intervención alguna en el ejemplar lucentino, que conserva la policromía original y presenta evidente suciedad en los ojos de cristal.

Arch. esp. arte, LXXXIX, 354, ABRIL-JUNIO 2016, 202-209

ISSN: 0004-0428, eISSN: 1988-8511, doi: 10.3989/aearte.2016.14 
oración, en ademán retórico, debe relacionarse con el gesto que demuestran algunas de sus dolorosas de busto medio, como las de Alba de Tormes, Zamora o Valladolid.

El escultor ha concedido una especial atención a las arrugas, talladas de un modo análogo en rostro, cuello y muñecas. El modo de interrumpirlas a la altura de las clavículas también resulta idéntico en los dos casos estudiados, pues lógicamente la talla se vuelve más sumaria en las partes que serán tapadas con las vestiduras. Esta atención al natural resulta especialmente significativa, pues la representación de la vejez constituye una de las lecciones de anatomía más difíciles de abordar, demostrando una vez más el alto grado de virtuosismo técnico que Mena logró alcanzar sobre la madera ${ }^{21}$.

Mención aparte merecen los ojos de cristal, que en ambos casos -al igual que en el ejemplar granadino de San Antón- son azules. Esta inusual coloración de las pupilas, que rara vez aparece en la escultura española, también delata la huella de Mena, pues como hemos visto el escultor la empleó en algunas de sus imágenes infantiles y en algunas representaciones femeninas, como ocurre en las dos esculturas orantes de Isabel la Católica de las catedrales de Granada y Málaga ${ }^{22}$.

No está claro si esta imagen del apóstol se concibió para figurar aislada o se hizo pensando en formar grupo con el Cristo a la Columna al que rendía culto la hermandad ${ }^{23}$. Conviene recordar que la iconografía de San Pedro arrepentido postrado ante Jesús flagelado halló cierto predicamento en el arte español de la Edad Moderna, especialmente en lo que respecta a la Baja Andalucía ${ }^{24}$. Se trata de un tema absolutamente apócrifo, pues según los evangelios el episodio de las tres negaciones se produjo en el patio de la casa de Caifás, durante la comparecencia de Jesús ante el Sumo Sacerdote, pero en ningún momento señalan que Pedro tuviera luego ocasión de mostrar su arrepentimiento durante el episodio de la flagelación. Más que en el relato evangélico, la iconografía parece inspirarse en las revelaciones de Santa Brígida ${ }^{25}$ y constituye todo un alegato en favor del sacramento de la penitencia: mientras que éste había sido negado por la doctrina protestante, se convirtió en una de las señas distintivas de la Iglesia militante de la Contrarreforma, que se encargó de su exaltación plástica a través de obras tan elocuentes como la propia Magdalena penitente de Mena.

Dado que la primera salida procesional de este San Pedro tuvo lugar meses antes del fallecimiento del escultor (octubre de 1688), no sería descabellado pensar que, dentro de la cronología propuesta, su ejecución estuviera más cercana a este último año que a la fecha fundacional de la hermandad. De ser así, estaríamos ante una de las últimas creaciones del granadino que, por su vigor de modelado y prodigiosa intensidad expresiva, demostraría la vitalidad del genio creativo de Mena aun en sus últimos años de vida.

${ }^{21}$ Similar tratamiento de la superficie lignaria reaparece en varias de sus representaciones de San Pedro Alcántara, de rostro ajado y apariencia enjuta, como los de la iglesia de San Antón de Granada y el del convento de la Madre de Dios de Lucena. En todos los casos se ha empleado una finísima capa de aparejo para no ocultar los pormenores de la talla.

${ }^{22}$ Otra excepción a la norma la constituye Pedro Duque Cornejo, quien, ya en el siglo XVIII, rescata el uso de los ojos de cristal azules.

${ }^{23}$ Aunque consta que desde el siglo XVIII el "paso" de las lágrimas de San Pedro se representaba con la imagen aislada del apóstol y el elemento parlante del gallo sobre la columna, es posible que para su disposición en el altar de la capilla se agregase al Cristo de las Penas -el Cristo a la Columna que mencionan los documentos- para simular dicha iconografía apócrifa, pues aunque se trata de un Jesús de la Humildad y Paciencia, hay que recordar que está sentado junto a una columna. En el siglo XVIII, esta escultura de papelón sería sustituida por una nueva de madera, conservada actualmente en la iglesia de Nuestra Señora del Carmen de Estepa. Jordán Fernández, 2003: 44. Mateos Llamas, 2003: 78.

${ }^{24}$ Pérez Sánchez, 2000: 17-20. Para un reciente análisis de esta iconografía en el caso hispalense, véase Reyes de la Carrera, 2013.

${ }^{25}$ Reyes de la Carrera, 2013: 44-46. 


\section{BIBLIOGRAFÍA}

Aguilar y Cano, Antonio (1888): Memorial Ostipense: extracto de varios curiosos libros que se ocupan de la antigua Ostippo ú Stippo y actúal Estepa. Estepa: Imp. de don Antonio Hermoso Cordero, tomo II.

Alonso Moral, Roberto (2007): "La scultura lignea napoletana in Spagna nell'età del barocco: presenza e influsso". En: Casciaro, Raffaele/Cassiano, Antonio (coords.): Sculture di età barocca tra Terra d'Otranto, Napoli e Spagna [cat. exp.]. Roma: De Luca, pp. 75-86.

Ceán Bermúdez, Juan Agustín (1800): Diccionario Histórico de los más Ilustres Profesores de las Bellas Artes en España. Madrid: Imp. de la viuda de Ibarra, tomo III.

Díaz Fernández, Ezequiel (2003): “La imagen de San Pedro en el arte sacro estepeño". En: Caballero Páez, Moisés (coord.): $50^{\circ}$ Aniversario de la Reorganización de la Hermandad de San Pedro. Estepa: Pontificia Real Hermandad de San Pedro Apóstol, pp. 95-110.

Fernández Flores, José (2000): Vere nullius: la Vicaría de Estepa. Estepa: Ayuntamiento.

García Luque, Manuel (2011-2012): “A propósito de un agente de Pedro de Mena en Lucena: el pintor Bernabé Ximénez de Illescas”. En: Boletín de Arte, 32-33, Málaga, pp. 281-309.

García Luque, Manuel (2013): "Don Luis de Guzmán, contador del duque de Medinaceli, y el Lavatorio de Pedro de Mena". En: Anuario del Departamento de Historia y Teoría del Arte, 25, Madrid, pp. 61-74.

Gila Medina, Lázaro (2007): Pedro de Mena, escultor: 1628-1688. Madrid: Arco/Libros.

Henares Cuéllar, Ignacio / Félez Lubelza, Concepción / Orozco Díaz, Emilio (1970): Centenario de Alonso Cano en Granada, tomo II [cat. exp.]. Madrid: Ministerio de Educación y Ciencia.

Hernández Díaz, José / Sancho Corbacho, Antonio / Collantes de Terán, Francisco (1955): Catálogo arqueológico y artístico de la provincia de Sevilla. Sevilla: Diputación, tomo IV.

Jesús, Teresa de (O.C.D.) [1565 (1915)]: "Libro de la Vida”. En: Obras de Santa Teresa de Jesús, edición de Silverio de Santa Teresa, tomo I. Burgos: El Monte Carmelo.

Jordán Fernández, Jorge Alberto (2003): “Una aproximación a los orígenes de la Hermandad de San Pedro". En: Caballero Páez, Moisés (coord.): $50^{\circ}$ Aniversario de la Reorganización de la Hermandad de San Pedro. Estepa: Pontificia Real Hermandad de San Pedro Apóstol, pp. 29-51.

Mateos Llamas, José Javier (2003): "La hermandad de San Pedro en la Semana Santa del Barroco". En: Caballero Páez, Moisés (coord.): $50^{\circ}$ Aniversario de la Reorganización de la Hermandad de San Pedro. Estepa: Pontificia Real Hermandad de San Pedro Apóstol, pp. 61-93.

Orueta y Duarte, Ricardo de (1914): Pedro de Mena. Madrid: Centro de Estudios Históricos.

Pérez Sánchez, Alfonso E. (2000): "Las lágrimas de San Pedro: iconografía de San Pedro penitente en la pintura española”. En: Pérez Sánchez, Alfonso E. (com.): Las lágrimas de San Pedro en la pintura española del Siglo de Oro [cat. exp.]. Bilbao: Museo de Bellas Artes de Bilbao, pp. 13-31.

Reyes de la Carrera, Manuel Ramón (2013): "La iconografía de Cristo atado a la Columna con San Pedro arrepentido en las hermandades de Sevilla y su provincia”. En: Roda Peña, José (dir.): XIV Simposio sobre Hermandades de Sevilla. Sevilla: Fundación Cruzcampo, pp. 41-72.

Romero Torres, José Luis (1989): “El artista, el cliente y la obra de arte”. En: Sánchez-Mesa Martín, Domingo (com.): Pedro de Mena: III centenario de su muerte 1688-1988 [cat. exp.]. Málaga: Junta de Andalucía, pp. 97-114.

Romero Torres, José Luis (2014): "San Pedro de Alcántara". En: Bray, Xavier/Romero Torres, José Luis: Pedro de Mena: The Spanish Bernini [cat. com.]. Madrid: Coll \& Cortés Collection, pp. 139-157.

Sánchez López, Juan Antonio (2004): "La pasión según Andalucía". En: Fernández de Paz, Esther (coord.): Artes y Artesanías de la Semana Santa andaluza. Sevilla: Tartessos, tomo II, pp. 152-203.

Sánchez-Mesa Martín, Domingo (1967): "Algunas noticias sobre la obra de Pedro de Mena". En: Archivo Español de Arte, 40, 159, Madrid, pp. 245-262.

Valladar, Francisco de Paula (1915): "Más noticias acerca de Pedro de Mena". En: La Alhambra. Revista quincenal de Artes y Letras, 410, Granada, pp. 169-172.

Verdejo Martín, Antonio (2006): La historia a través del Archivo Parroquial de Íllora (Granada): la devoción. La cofradía de la Santa Vera Cruz, Santo Cristo de San Marcelo y Jesús Nazareno. Granada: Autoedición.

Villar Movellán, Alberto (dir.) (1995): Guía artística de la provincia de Córdoba. Córdoba: Universidad.

Fecha de recepción: 09-XII-2014

Fecha de aceptación: 17-VI-2015

Arch. esp. arte, LXXXIX, 354, ABRIL-JUNIO 2016, 202-209

ISSN: 0004-0428, eISSN: 1988-8511, doi: 10.3989/aearte.2016.14 